\title{
Assessment of sufficiency of financial resources according to plan of investment project of cooperation in the field of agriculture
}

\author{
Sergey Sinenko ${ }^{1}$ and Ivan Savin ${ }^{1, *}$ \\ ${ }^{1}$ Moscow State University of Civil Engineering, 129337, Yaroslavskoye Shosse, 26, Moscow, Russia
}

\begin{abstract}
The choice of an investment project is based on all the information collected and obtained at all the previous stages of the formulation of the project, the choice of the most effective for the implementation of the investment project from the whole set of alternative ones is made. The main task to be solved in determining the financial viability of a project is to assess its ability at all stages of development to timely and fully respond to the existing financial obligations, that is, to assess the solvency and liquidity of the project. Financing of entrepreneurial firms is a set of forms and methods, principles and conditions of financial support for simple and extended reproduction. When calculating economic efficiency, the discounting method is used, for the need to compare the values of cash receipts and payments, spaced over time. In the economic assessment of efficiency in this work, a dynamic method based on discounting was used.
\end{abstract}

\section{Introduction}

Recently, the state has taken certain steps to develop and implement tax legislation aimed at expanding the possibilities of using its own financial resources in order to develop the country's economy [1-4].

The purpose of this work is to assess the financial stability of an investment project using various coefficients for assessing the effectiveness of the project.

Investment activity in the real sector of the economy in the Russian Federation is determined by the Federal Law "On investment activity in the Russian Federation carried out in the form of capital investments" No. 39-FZ dated 25.02.1999. [1]

As a conclusion, we can say that investment activity is aimed at solving the strategic tasks of developing an industrial enterprise, creating the necessary material and technical prerequisites for this. It is closely related to operational activities, that is, with the processes of production and sales of products. That is why in the period of drastic changes in the economy, technology, ecology and politics, survival and success in the business world depends to a large extent on the correctness of the investment decisions made. An investment decision is one of the most important business initiatives to be undertaken by

\footnotetext{
*Corresponding author: savin.vanya2013@gmail.com
} 
entrepreneurs or managers, since investments tie financial resources over a relatively long period of time. The investment decision is embodied in an investment project [5-8].

\section{Methods}

For the pre-investment phase of the implementation of the investment project, it is necessary to preliminarily substantiate the investment concept, to determine what strategic goals the enterprise can achieve within the framework of the implementation of the investment concept under consideration. Next, it is necessary to outline and then clearly state the designated goals that it must achieve, and the tasks that it must solve in the framework of the implementation of the future investment project. This approach is relevant if the investment plan is primary. However, there are situations when a company is given clear goals and objectives within the framework of the strategy, and its management needs to develop and formulate an investment idea in accordance with them, through which it will solve and achieve the set tasks and goals. At the same stage, the formulated investment ideas should be coordinated with potential participants in the future investment project, and, if necessary, with federal, regional and sectoral management bodies. Often, the company's management approves an investment project without proper analysis of the options available. In our opinion, this approach is incorrect, it leads to the adoption of not always effective decisions and does not allow maximizing the process of achieving and solving the set goals and objectives. Therefore, at this stage it is necessary to consider alternative options for the implementation of the investment project. It is possible that all considered alternatives can bring profit to the company and return the resources invested in the project, but the company needs to make only one investment decision, which will be the most profitable and effective. When the implementation of one of the investment projects makes it impossible to make a profit from the rest of the projects, such investment projects are called mutually exclusive or alternative. There are no universal recipes applicable in all economic feasibility studies for investment projects. At the same time, there are methods that allow you to structure and unify the process of conducting a project justification. The Industrial Feasibility Study Guide developed by the United Nations Industrial Development Organization (UNIDO) is one of the most comprehensive documents describing how to conduct a business case. It is clear that other methodological documents can be used in the process of economic justification. The choice of a methodology for collecting information and carrying out calculations is a task whose solution depends on the specific features of the project and the conditions for its implementation.

In this work, only the financial and economic assessment of the project will be considered. This section of the investment project is the most important and is performed in the following order:

1. Assessment of the commercial efficiency of an investment project:

- production and sales costs;

- general capital investments (investments);

-report about incomes and material losses;

- cash flows and performance indicators;

- assessment of the sustainability of the investment project

2. Evaluation of the effectiveness of participation in the project for enterprises and shareholders:

- drawing up the financial and investment budget of the project;

- assessment of the financial feasibility of the project and calculation of indicators of the effectiveness of the company's participation in the project

An investment project is not only a form of implementing the adopted investment decision, but also a form of resolving numerous contradictions that arise in the decision- 
making process. The effectiveness of an investment project is a category that reflects its compliance with the goals and interests of the project participants. A full assessment of the viability of an investment project is possible only with a thorough and in-depth analysis of its financial feasibility and economic efficiency. The scheme for conducting a full assessment of the viability of the project is shown in Fig. 1.2.

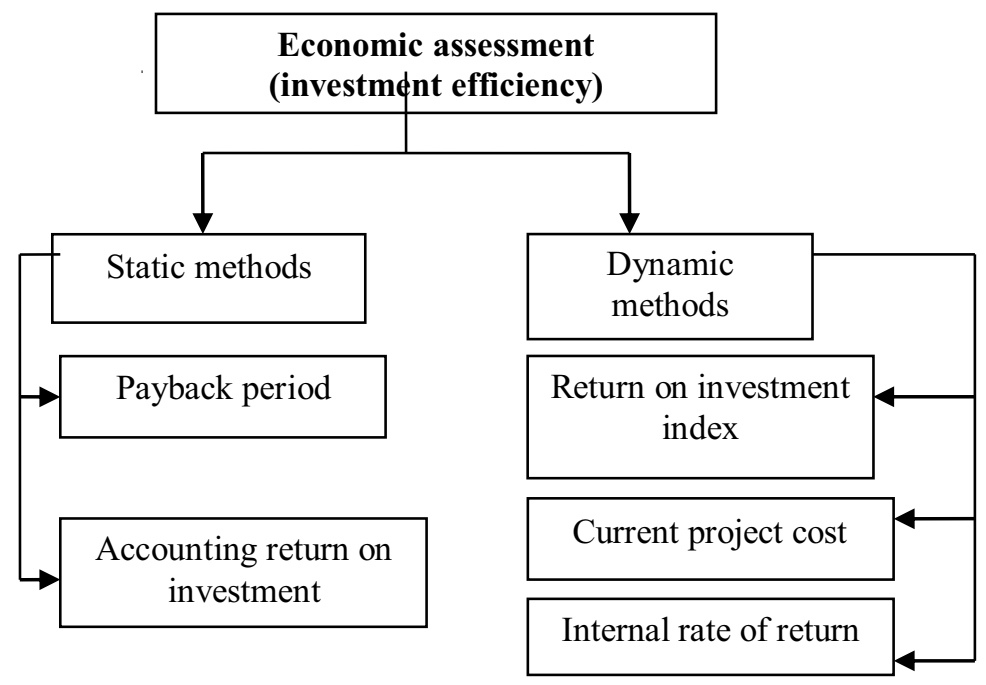

Fig. 1. Scheme of economic evaluation of an investment project.

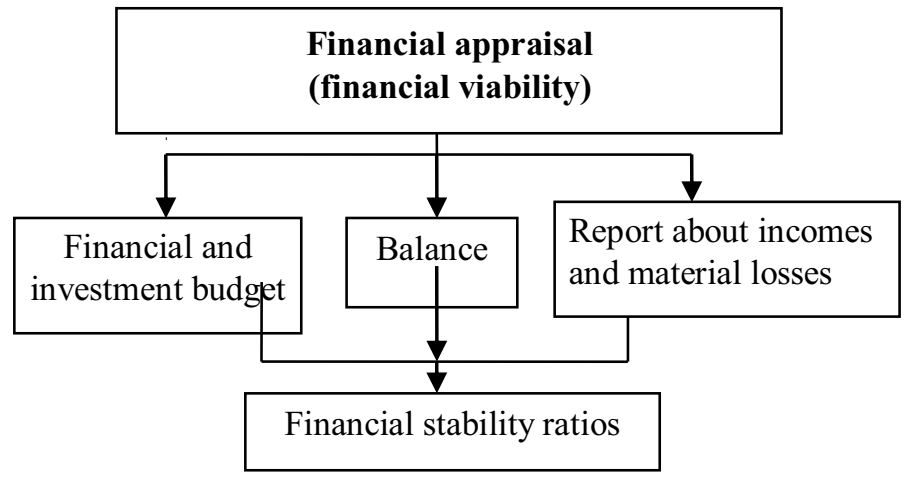

Fig. 2. Scheme of financial evaluation of an investment project

\section{Results}

\subsection{Effectiveness of the investment project}

The effectiveness of an investment project is determined to solve a number of problems:

- assessing the potential feasibility of implementing the project, ie checking the condition according to which the aggregate results exceed the costs of all types in an amount acceptable to investors;

- evaluating the advantages of the considered project in comparison with alternative ones; 
- ranking projects according to the adopted system of performance indicators with the aim of their subsequent inclusion in the investment program in conditions of limited financial and other resources.

The problem of assessing the economic efficiency of an investment project is to determine the level of its profitability in absolute and relative terms, which is usually characterized as the rate of return. There are two approaches to solving this problem: based on the use of simple, integrated methods and methods that take into account the change in technical and economic indicators at each step of the billing period, the unequal value of cash flows over time, investment risks, the interests of various groups of investors - project participants. The first one proposes the construction of statistical models, and the latter dynamic models, interrelated parameters necessary to assess the effectiveness. Therefore, they are often referred to as statistical and dynamic methods for evaluating performance. Significant shortcomings of statistical methods for assessing efficiency do not allow them to be recommended as a tool for developing a preliminary and, moreover, a final feasibility study of an investment project. The disadvantages of the statistical method can be fully eliminated by using the second group of economic efficiency methods - dynamic.

Efficiency assessment is recommended to be carried out according to the system of the following interrelated indicators:

- net present, or current, value - NPV;

- index of profitability or profitability - PI;

- payback period - DPP;

- internal rate of return (profit) - IRR.

The main purpose of assessing the financial condition of an investment project is to obtain a small number of key parameters that give an objective and accurate picture of the financial condition of the object in which investments are made. To make decisions about investment activities, a manager needs constant awareness of the relevant issues, which is the result of selection, concentration of initial information, assessment and analysis of the obtained financial performance indicators. Financial liabilities include all payments related to the implementation of the project under development: loan repayment, bill payment, salary payment, tax transfer. If this is not achieved at some stage (step) of the calculation period, then the project should be rejected (or revised). As highly effective as it is, insolvency is evidence of bankruptcy.

Financial analysis of an investment project is an essential element of the financial management of investment activities, which allows optimizing the interests of its various participants. The owners assess the financial condition in order to increase profitability and ensure the stability of the enterprise, so as to minimize their risks on the loans provided. The interests of various participants in investment activities allow us to reflect the corresponding indicators for assessing the financial viability of an investment project. (tab. 1).

Table 1. Relationship between financial indicators and investor interests

\begin{tabular}{|l|l|}
\hline Indicators & Subjects of financing \\
\hline - Amount of working capital; & Short-term lenders \\
- General liquidity ratio; & \\
- Ratio of immediate liquidity; & \\
- Turnover of receivables; & \\
- Turnover of commodity assets & \\
\hline - Ratio of coverage of interest on loans; & Long-term investors \\
- The ratio between borrowed and equity capital; & \\
- The ratio of borrowed capital to total assets; & \\
- General solvency ratio & \\
\hline
\end{tabular}


- Rate of earnings per share;

Investors-shareholders

- Rate of return on equity;

- Stock quotes ratio;

- Indicator of payment of dividends;

- Stock returns;

- The ratio of price to rate of earnings per share;

- Growth sustainability ratio

\subsection{Indicators for assessing the financial reliability of the project and the methodology for their determination.}

The initial information required to assess the financial condition of an investment project is the financial and investment budget, balance sheet and profit and loss statement. All these documents contain forecast (calculated) indicators for the planned billing period. For calculating indicators of financial condition (reliability), the same initial information is used as for calculating indicators of economic efficiency of investments. The specificity here lies in the fact that the linking of all activities of the projected firm (company) to justify the balance of the need for resources and their financial support is carried out by calculating the flows of real money. Bringing cash flows into a comparable form (using discounting), as suggested by the methodology for calculating economic efficiency indicators, is not required here.

The financial investment budget is the basis for calculating a number of indicators of the financial viability of a project and is usually requested by financial institutions when making lending decisions. It determines the ratio between the cash inflow from sales proceeds and attracted sources of investment financing and their outflow, formed due to the cost of production (without depreciation), the increase in fixed assets, loan payments.

The result of such a calculation is to determine the availability of free funds, which are one of the most important financial results of an investment, it is the financial feasibility of an investment project.

The financial and investment budget is a summary table of the results of calculations of all indicators carried out in the process of preparing aggregate information. It occupies a key position for the feasibility study of the project.

An important feature of constructing cash flows is that they are all displayed in time periods corresponding to the planned dates (time periods) of payments, i.e. taking into account the delay in payment for the products sold, the delay in payments for the supply of raw materials and materials, the conditions for the sale of products on credit, with advance payments, as well as the conditions for the formation of inventories and stable liabilities. Since these features of the formation of cash flows are essential for balancing income and costs, it is advisable to develop a financial and investment budget in increments of less than a year.

The economic assessment of investment projects is central to the process of justifying and selecting possible options for investing in operations with real assets. With all other favorable characteristics of the project, it will never be accepted for implementation if it does not provide:

- reimbursement of invested funds at the expense of income from the sale of goods or services;

- making a profit that ensures a return on investment not lower than the level desired for the enterprise;

- return on investment within a period acceptable to the enterprise.

For an accurate and complete description of the financial stability of an investment project, a relatively small number of financial ratios are sufficient. 


\subsection{Methods for determining the financial condition of the enterprise}

Currently, a large number of methods are used to determine the financial condition of an enterprise. In order to assess the financial attractiveness of an investment project, it is advisable to present the financial viability of two interrelated groups of indicators: solvency and liquidity.

The solvency of the project means the possibility of repayment on time and in full of the debt obligations arising in connection with the implementation of the investment project. To assess solvency, it is recommended to calculate a number of private indicators. (tab. 2)

Table 2. Solvency ratios

\begin{tabular}{|l|l|}
\hline Indicator & Calculation algorithm \\
\hline Financial stability ratio & $\begin{array}{l}\text { The ratio of the total of own and long-term borrowed funds to the balance sheet } \\
\text { currency of the enterprise }\end{array}$ \\
\hline Solvency ratio & $\begin{array}{l}\text { The ratio of borrowed funds (the total amount of long-term and short-term debt) } \\
\text { to equity }\end{array}$ \\
\hline $\begin{array}{l}\text { Long-term borrowing } \\
\text { ratio }\end{array}$ & $\begin{array}{l}\text { Ratio of long-term debt to the total amount of capitalized funds (the amount of } \\
\text { equity and long-term loans) }\end{array}$ \\
\hline $\begin{array}{l}\text { Coverage ratio of long- } \\
\text { term liabilities }\end{array}$ & Ratio of long-term debt to non-current assets (capital investments) \\
\hline
\end{tabular}

So, a solvent is a project that can pay off its long-term obligations. At the same time, the enterprise must timely fulfill its current obligations related to the implementation of the investment project. The ability of an investment project to timely fulfill its current (shortterm) obligations by selling current assets is called the project's liquidity. Assessment of the financial condition of the project is based on the same initial and integrated economic information that is used to assess the economic efficiency of investments. The calculations are carried out at the same planning intervals as for economic efficiency. Since the indicators of economic efficiency and indicators of financial reliability are constructed on the basis of balanced flows of real money (in one case, accumulated in the financial and investment budget, and in the other in the balance sheet), having a common information base, the system of such indicators becomes balanced.

From the above, two important conclusions can be drawn. First, the justification of the management decision on investment must be carried out only on the basis of a balanced scorecard, keeping in mind the requirements of investors to the level of each of them.

Secondly, the procedures followed by the economist-manager to achieve a balanced scorecard are an important project management tool in order to achieve an acceptable level of profitability for investors. Complex logical connections of the system of flows and indicators predetermine the sequence of analysis and adjustment of performance indicators from indicators of financial reliability (solvency, liquidity) to cash flows in the balance sheet and financial and investment budget and, ultimately, to indicators of economic efficiency.

\section{Discussion}

The financing of firms - companies is understood as the process of generating funds, or more broadly, the process of forming the capital of a firm in all its forms. The concept of "financing" is quite closely related to the concept of "investment", if financing is the formation of funds, then investing is their use. Both concepts are interrelated, but the first precedes the second. It is impossible for a firm to plan any investments without funding sources. At the same time, the formation of the company's financial resources occurs, as a rule, taking into account the plan for their use. 
When choosing sources of financing for an enterprise, it is necessary to solve five main tasks:

1) determine the needs for short and long-term capital;

2) identify possible changes in the composition of assets and capital in order to determine their optimal composition and structure;

3 ) to ensure constant solvency and, therefore, financial stability;

4) use own and borrowed funds with maximum profit;

5) reduce the cost of financing economic activities.

\subsection{An example of an investment project}

Analysis and selection of an investment project on the example of the construction of a sports center on the street Molodogvardeyskaya in ZAO Moscow. The object was built according to an individual architectural plan. It is based on a monolithic foundation, bearing structures are made of reinforced concrete, brick finish. The floors are decorated with a cement screed, radiators with thermostats are installed, the windows have three-chamber double-glazed windows. There are two car parks near the building, they are underground (136 car places) and aboveground (63 car places) car parks. The first floor of the building is non-residential. There is a cafe, a changing room. A house adjoins the sports center. The inner semi-open courtyard of the complex is landscaped. Walking paths have been laid among the trees planted in the alleys, original landscape compositions and lush flower beds have been created.

The required volume of investments is 10482200 \$.

The initial costs should be financed by obtaining a loan from the founders at the required rate of return in the amount of $18 \%$ and $81 \%$ at the expense of a loan received for the project for 5 years at $16 \%$ per annum with an annual payment and repayment by the method of reducing the balance. The income tax rate is $24 \%$, the unified social tax is $26 \%$ $[9,10]$.

The discount method uses a rate that is usually called the discount rate (possible options: "comparison rate", "barrier rate", "discount rate", "reduction factor", etc.). A qualitative assessment of the effectiveness of an investment project largely depends on the choice of the discount rate.

The indicators of the commercial efficiency of the project are determined on the basis of cash flows, the calculation of which is made on the basis of the data determined by the steps of the calculation period:

- costs of production and sales of products,

- total capital investment (investment)

- report about incomes and material losses

- cash flows and performance indicators.

When calculating the costs of production and sales of products (services), the grouping of costs is not of fundamental importance. However, when performing these calculations, the following rules must be observed:

- allocate depreciation charges in a separate item;

- to group costs in such a way that costs could be divided into conditionally fixed and conditionally variable.

Below are the calculations of general production costs, which are subsequently grouped and summarized in one table of production costs and sales of products (services) 
Table 3. Costs of production and sale of premises (thousand \$.)

\begin{tabular}{|c|c|c|c|}
\hline \multirow{2}{*}{\multicolumn{2}{|c|}{ Indicator }} & \multicolumn{2}{|c|}{ step of the calculation period } \\
\hline & & \multirow{2}{*}{$\begin{array}{r}20 \ldots \\
13020.01\end{array}$} & \multirow{2}{*}{$\begin{array}{r}20 \ldots \\
16075.08\end{array}$} \\
\hline $\begin{array}{l}\text { general operating expenses } \\
\text { without depreciation of fixed } \\
\text { assets (thousand \$) }\end{array}$ & Total & & \\
\hline $\begin{array}{l}\text { general operating expenses } \\
\text { excluding depreciation of fixed } \\
\text { assets (thousand \$) }\end{array}$ & Total & 5410.39 & 4848.56 \\
\hline \multirow{13}{*}{$\begin{array}{l}\text { costs of production and sale of } \\
\text { premises (thousand \$.) }\end{array}$} & 1. Production volume & 33490 & 33490 \\
\hline & 2. Direct material costs & 844.45 & 844.45 \\
\hline & 3. Labor costs & 5760 & 5760 \\
\hline & $\begin{array}{ll}4 . & \text { Depreciation } \\
\text { deductions } & \end{array}$ & 9357.24 & 5347.21 \\
\hline & $\begin{array}{l}\text { 5. Taxes charged to the } \\
\text { cost }\end{array}$ & 1497.6 & 1638 \\
\hline & $\begin{array}{l}\text { 6. General production and } \\
\text { general operating } \\
\text { expenses excluding } \\
\text { depreciation charges and } \\
\text { taxes attributed to the } \\
\text { prime cost }\end{array}$ & 16932.77 & 19285.64 \\
\hline & 7. Production costs & 34392.04 & 33415.3 \\
\hline & $\begin{array}{l}\text { 8. Production costs } \\
\text { without depreciation }\end{array}$ & 25034.82 & 28068.09 \\
\hline & 9. Sales costs & 0 & 0 \\
\hline & $\begin{array}{l}\text { 10. Costs of production } \\
\text { and sales of products }\end{array}$ & 34392.04 & 33415.3 \\
\hline & $\begin{array}{l}\text { 11. Costs of production } \\
\text { and sales of products } \\
\text { without depreciation }\end{array}$ & 25034.82 & 28068.09 \\
\hline & $\begin{array}{l}\text { 12. Production cost per } \\
\text { unit }\end{array}$ & 5.13 & 4.99 \\
\hline & 13. Gross unit cost & 5.13 & 4.99 \\
\hline \multirow{7}{*}{$\begin{array}{l}\text { total capital investments } \\
\text { (investments) }\end{array}$} & 1. Fixed assets & 10482200 & 0 \\
\hline & 2. Intangible assets & & 0 \\
\hline & $\begin{array}{l}\text { 3. Total: costs of non- } \\
\text { current assets }\end{array}$ & 10482200 & 0 \\
\hline & $\begin{array}{l}\text { 4. Other (non-capitalized) } \\
\text { work and costs }\end{array}$ & 2205440 & 0 \\
\hline & 5. Commissioning & 314466 & 0 \\
\hline & $\begin{array}{l}\text { 6. Substitution of fixed } \\
\text { assets and intangible } \\
\text { assets }\end{array}$ & 0 & 2096440 \\
\hline & $\begin{array}{lcc}7 . & \text { Total } & \text { investment } \\
\text { (investment) } & \end{array}$ & 13002106 & 0 \\
\hline \multirow{2}{*}{$\begin{array}{l}\text { profit and loss statement } \\
\text { (financial results) (thousand \$) }\end{array}$} & 1. Sales volume (pcs.) & 33490 & 33490 \\
\hline & 2. Unit price & 8.4 & 8.4 \\
\hline
\end{tabular}




\begin{tabular}{|c|c|c|c|}
\hline & $\begin{array}{l}\text { 3. Revenue }+ \text { other and } \\
\text { non-operating income }\end{array}$ & 5617.75 & 16447.94 \\
\hline & $\begin{array}{l}\text { 4. Costs of production and } \\
\text { sales without depreciation }\end{array}$ & 19624.43 & 23219.53 \\
\hline & $\begin{array}{ll}5 . & \text { Depreciation } \\
\text { deductions } & \\
\end{array}$ & 9357.24 & 5347.21 \\
\hline & $\begin{array}{l}\text { 6. Cost of goods, } \\
\text { products, works, services } \\
\text { sold }\end{array}$ & 28981.66 & 28566.74 \\
\hline & 7. Gross profit & 27181.09 & 28317.2 \\
\hline & 8. Selling expenses & 0 & 0 \\
\hline & $\begin{array}{ll}\begin{array}{l}9 . \\
\text { expenses }\end{array} & \text { Administrative } \\
\end{array}$ & 999.89 & 4848.56 \\
\hline & 10. Profit (loss) from sales & 21770.7 & 23468.62 \\
\hline & 11. Income tax & 5224.98 & 5632.47 \\
\hline & 12. Net profit & 16545.74 & 17836.16 \\
\hline & 13.Calculating net profit & 49343.63 & 133839.39 \\
\hline & 14. Income & 25902.95 & 23183.38 \\
\hline & $\begin{array}{l}\text { 15. Income on a } \\
\text { cumulative basis }\end{array}$ & 77450.25 & 200607.11 \\
\hline cash flows for assessing the & 1. Cash inflows & 56162.75 & 56883.94 \\
\hline $\begin{array}{l}\text { commercial efficiency of the } \\
\text { project as a whole (thousand \$) }\end{array}$ & $\begin{array}{l}\text { 1.1. Revenue from sales of } \\
\text { products }\end{array}$ & 56162.75 & 56883.94 \\
\hline & $\begin{array}{l}\text { 1.2. Other and non- } \\
\text { operating income }\end{array}$ & 0 & 0 \\
\hline & 2. Cash outflows & 31127.38 & 29175.51 \\
\hline & $\begin{array}{l}\text { 2.1. Costs of production } \\
\text { and sales of products, } \\
\text { excluding depreciation } \\
\text { charges }\end{array}$ & 23466.43 & 27088.53 \\
\hline & $\begin{array}{ll}\begin{array}{l}2.2 . \\
\text { expenses }\end{array} & \text { Non-operating } \\
\end{array}$ & 7660.96 & 2087 \\
\hline & $\begin{array}{l}\text { 3. Balance of cash flow } \\
\text { from operating activities }\end{array}$ & 25035.35 & 27708.42 \\
\hline & $\begin{array}{l}\text { 4. Cash inflows (residual } \\
\text { value) }\end{array}$ & 0 & 721.19 \\
\hline & 5. Cash outflows & 0 & 2096.44 \\
\hline & $\begin{array}{ll}5.1 . \quad \text { Total } & \text { capital } \\
\text { expenditures } \\
\text { (investments) }\end{array}$ & 0 & 2096.44 \\
\hline & $\begin{array}{ll}5.2 . \quad \text { Investments } & \text { in } \\
\text { additional funds } & \\
\end{array}$ & 0 & 0 \\
\hline & $\begin{array}{l}\text { 6. Balance of cash flow } \\
\text { from investment activities }\end{array}$ & 0 & -1375.25 \\
\hline & $\begin{array}{l}\text { 7. Balance of two flows } \\
\text { (net cash receipts of the } \\
\text { project) }\end{array}$ & 25035.35 & 26333.17 \\
\hline & $\begin{array}{l}\text { 8. The same cumulative } \\
\text { total }(\mathrm{NV}(\mathrm{m}))\end{array}$ & 11650.49 & 132872.07 \\
\hline
\end{tabular}




\subsection{Calculations}

The cash flow from investment activities as an outflow includes, first of all, the costs of creating and putting into operation new fixed assets and liquidation, replacing retiring existing fixed assets, distributed over the steps of the calculation period. This also includes non-capitalizable costs (for example, payment of tax on a land plot used in the course of construction, expenses for the construction of external infrastructure facilities, etc.). In addition, changes in working capital are included in the cash flow from investing activities (an increase is considered an outflow of funds, a decrease is an inflow). The outflow also includes own funds invested in the deposit, as well as the costs of purchasing securities of other economic entities intended to finance this investment project.

The source of information is pre-project and design materials, studies of the Russian and foreign markets, confirmed, for example, by intergovernmental agreements, agreements of intent, concluded contracts, etc.

For a number of investment projects, it may be difficult to strictly delineate flows for different types of activities. In these cases, as well as in the preliminary stages of investment planning, it is possible to combine some (or all) flows.

Let's consider in detail the calculations of these indicators. The key assessment criterion - the net present value (NPV) - is the sum of all cash flows (receipts and payments) arising during the period under consideration, reduced (recalculated) at one point in time, which, as a rule, is the moment when the investment begins, that is, 2007 and is calculated by the formula:

$$
N P V=\sum_{t=1}^{n} \frac{C F_{t}}{(1+r)^{t}}-I_{0}
$$

where: $r$ - discount rate; $n$ is the number of periods of the project implementation; $C F_{t}$ is the net flow of payments in period $t$. $I_{0}$ - the amount of initial costs, i.e. the amount of investment at the beginning of the project;

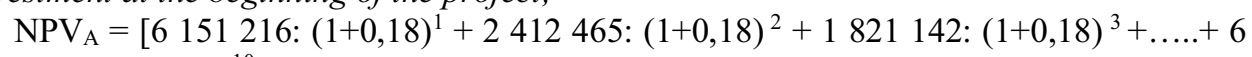
$\left.774638:(1+0,18)^{10}\right]-13002106=3029784$

A positive NPV indicates that the project's net cash flows cover investment costs, which means the project is profitable and can be accepted for implementation.

The method for estimating the internal rate of return (IRR) uses the concept of present value. The meaning of calculating this ratio when analyzing the effectiveness of planned investments is as follows: IRR shows the maximum allowable relative level of expenses that can be associated with a given project.

In other words, this method is reduced to finding a discount rate at which the current value of the income expected from the investment project will be equal to the current value of the required cash investments. The search for such a rate is determined in an iterative manner.

$$
C F O=\sum_{t=1}^{n} \frac{C F_{t}}{(1+I R R)^{t}}
$$

where: $r$-discount rate; $n$ is the number of project implementation periods; CFt is the net flow of payments in period $t$.

IRR A: $13002106=6151$ 216: (1 + IRR) 1 + 2412 465: (1 + IRR) $2+1821$ 142: $(1+$ IRR) $3+\ldots+6774638:(1+$ IRR $) 10=24 \%$

$24 \%$ show how much, on average, for the entire investment period, the company earns on these investments. If capital investments are made only at the expense of borrowed 
funds, as in our case, then the difference between the discount rate - $r$ and the internal rate of return IRR shows the effect of investment activity.

To find out if net cash prevails over investment costs, the profitability index PI is calculated using the following formula:

$$
P I=\sum_{t} \frac{C F_{t}}{(1+r)^{t}} / C F_{0}
$$

PIA $=\left[\begin{array}{l}6 \\ 151\end{array} 1216:(1+0.18) 1+2412465:(1+0.18) 2+1821142:(1+0.18) 3+6\right.$ 774 638: $(1+0,18) 10]: 13002106=1.23$.

If the result is greater than 1 , this means that the net cash covers the investment costs.

The rate of return on investment allows you to draw a conclusion about the project with the greatest return on investment.

Table 4.

\begin{tabular}{|l|l|}
\hline \multicolumn{1}{|c|}{ Criterion } & \multicolumn{1}{c|}{ Value } \\
\hline 1. Net Present Value (NPV) & 3029784 \\
\hline 2. Profitability index (PI) & 1.23 \\
\hline 3. Internal rate of return (IRR) & $24 \%$ \\
\hline 4. Payback period (DPP) 4 years 3 months. & 4 years 3 months \\
\hline
\end{tabular}

If we draw a conclusion on the basis of the results obtained, then we can see that the company will have an internal rate of return of $24 \%$, the level of profitability will be 1.23 .

Most of both domestic and foreign experts have come to the unanimous opinion that when analyzing alternative projects, the NPV (net present value), IRR (internal rate of return) and PI (investment return index) criteria are the most appropriate for making investment decisions.

In the case of limited resources and the need to get not a large mass of income, but the highest profitability, it is usually recommended to make a management decision based on the indicator of the internal rate of return (IRR).

The stage of assessing the effectiveness of participation in the project is carried out after clarifying the composition of the participants in the investment project and developing a financing scheme using digitalization [11]. Before calculating the indicators of the effectiveness of participation in the project, its financial feasibility is checked. A sufficient condition for the financial feasibility of an investment project is that the accumulated balance of the three flows (operational, investment and financial) is not negative at each step $\mathrm{m}$. This takes into account dividend payments.

Mathematically, the calculation of the effectiveness of the enterprise's participation in the project is performed in the same way as for the commercial assessment. Own (share) capital is considered as an outflow, and receipts remaining at the disposal of the designer after obligatory payments (including on borrowed funds) are considered as an inflow. The following changes are made to the calculation: sources of financing, cash flow from financial activities.

\subsection{Indicators of financial soundness}

The condition for the financial feasibility of an investment project is the continuity of the cash flow or non-negativity at each step $m$ of the accumulated balance of the cash flow. If at some step the accumulated cash flow balance becomes negative, this means that the project in this form cannot be implemented regardless of the values of the integral performance indicators. In this case, it is necessary to attract additional own or borrowed funds or change other parameters of the project. 
The most generalizing absolute indicator of financial stability is the correspondence or inconsistency (surplus or shortage) of sources of funds for the formation of reserves and costs, that is the difference between the size of sources of funds and the amount of reserves and costs. This refers to the provision of sources of own and borrowed funds, with the exception of accounts payable and other liabilities. It can be concluded that the project in question is both solvent and liquid at the same time. Some deviations in the indicators are attributed to external financing.

Business activity in the financial aspect is manifested, first of all, in the rate of turnover of funds. The acceleration of the turnover of circulating assets reduces the need for them, allowing the enterprise to release part of the circulating assets either for the needs of the national economy (absolute release) or for additional production (relative release). The rate of turnover of funds is a complex indicator of the organizational and technical level of an enterprise. The increase in the number of revolutions is achieved by reducing the production time and reducing the turnaround time. The production time is determined by the technological process and the nature of the equipment used; reduction of the circulation time is achieved by the development of specialization and cooperation, the improvement of direct interfactory relations, the acceleration of transportation, document circulation and settlement.

Management of current assets of an enterprise is associated with specific features of the formation of its operating cycle. The operating cycle is a period of full turnover of the entire amount of current assets, in the process of which there is a change in their individual types. The movement of the company's circulating asset in the process of the operating cycle goes through four main stages, successively changing its forms. The duration of the operating cycle (turnover of inventories and accounts receivable) for the project is $(25.77+$ $39.60)$ - 65.37 days, which deviates by $2-7 \%$ in terms of growth.

The calculation of profitability ratios, based on the above division, allows you to fully assess the efficiency of the enterprise. So, the profitability of products sold shows what profit the ruble of invested funds brings to the enterprise, but it does not allow assessing the efficiency of the enterprise's use of its assets: fixed and circulating assets and its liabilities: its own and borrowed funds. Evaluating the efficiency of using fixed and working capital allows the calculation of the return on assets ratio, which shows how many rubles of profit the ruble of all funds invested in the enterprise brings, but this indicator cannot give an answer: how effectively the enterprise uses its own and attracted sources of financing. Therefore, in order to answer the question whether the company is effectively using its own funds, whether it needs to attract additional loans and credits, the calculation of the return on equity ratio allows. Thus, the calculation and comparison of the coefficients of these three groups will make it possible to sufficiently illuminate the efficiency of the main activity of the enterprise, the use of assets and liabilities, to identify the prevailing trends, to make decisions on the necessary measures to increase the profitability of the enterprise.

\section{Conclusions}

Justification of an investment project in terms of its financial stability is very important when making a decision. It is when calculating the criteria used to assess the effectiveness of a project that managers make a choice of one or another project. In the economic assessment of efficiency in our work, we used a dynamic method based on discounting. This method includes the calculation of the following criteria: net present value NPV, profitability index PI, internal rate of return or project profitability IRR, payback period PP.

When calculating these criteria, it can be seen that most of the criteria indicate that the company will have the highest internal rate of return, it is about $24 \%$, the level of profitability will be 1.23 . Most of both domestic and foreign experts have come to the 
unanimous opinion that when analyzing alternative projects, the NPV (net present value), IRR (internal rate of return) and PI (investment return index) criteria are the most appropriate for making investment decisions.

During the analyzed period, the company has normal financial stability, however, has a downward trend. The main reason for the decline in the stability of the enterprise may be the growth of accounts receivable due to non-payments by consumers.

The capital structure of the enterprise is dominated by borrowed funds, which are presented in the form of long-term liabilities and accounts payable. Therefore, the company needs to reduce the attraction of borrowed capital, in the form of long-term obligations. In the course of its activities, the enterprise uses all its sources of financial resources and fully covers reserves and costs, and this is the main thing. Since the stock of sources of own funds is a stock of financial stability of an enterprise, provided that its own funds exceed borrowed funds [12-14]. Financial stability ratios allow not only assessing one of the aspects of the financial condition of the enterprise. With the correct use of them, you can actively influence the level of financial stability, increase it to the minimum required, and if it actually exceeds the minimum required level, you can use this situation to improve the structure of assets and liabilities.

Based on the above calculations, it can be concluded that the project is financially stable.

\section{References}

1. Federal Law "On investment activities in the Russian Federation, carried out in the form of capital investments" No. 39 dated 25.02.1999. (as revised on 02.08.2019). http://www.consultant.ru/document/cons_doc_LAW_22142/ (Last accessed 2021/02/23)

2. https://cheaphome.ru/en/klassifikaciya-investicii-po-obektu-investirovaniya-vidyinvesticii/ (Last accessed 2021/02/24)

3. https://all-sci.net/investitsii_987/investitsionnyiy-analiz-spb-piter-160-seriya.html (Last accessed 2021/02/25)

4. https://sfpk.at.ua/biblioteka/PMI/Project_upr.pdf (Last accessed 2021/02/23)

5. V. V. Kosov, V. N. Livshits, Methodological recommendations for assessing the effectiveness of investment projects, M-in econom (Moscow, Economics, 2000) https://doi.org/10.5901/mjss.2015.v6n4s4p22

6. E. G. Nepomniachtchi, Investment design. Tutorial. Taganrog. Publishing house TRTU (2003) https://patents.google.com/patent/US20050242186A1/en (Last accessed 2021/02/31)

7. Rimer M.I., Kasatov A.D., Matienko N.I. Economic evaluation of investments. 2 nd ed. - SPb.: Peter, 2007.- 480 p. Available at: https://sworld.education/konfer28/206.pdf (Last accessed 2021/02/31)

8. E. M. Sorokina, Analysis of the company's cash flows (Saint-Petersburg, Publishing house SPbGUEF, 2001) https://doi.org/10.24891/ea.16.11.2145

9. INTES LLC - CONSTRUCTION COMPANY. Available at: http://www.ooointes.ru (Last accessed 2021/02/31)

10. http: //mosopen.ru/document/388_rp_2005-03-18 (Last accessed 2021/02/31)

11. I. M. Savin, S. A. Sinenko, Experience in digitizing the services of public authorities in the transport sector, VIII International Scientific Conference Transport of Siberia 2020, 918-012181 https://doi.org/10.1088/1757-899x/918/1/012181 
12. S. A. Sinenko, I. N. Doroshin, Use of Modern Means and Methods in the Organization and Management in Construction, The International Conference on Materials Research and Innovation (ICMARI) 16-18 December 2019, Bangkok, Thailand (2020) IOP Conf. Ser.: Mater. Sci. Eng. 753042017 https://doi.org/10.1088/1757899x/753/4/042017

13. M. Fakhratov, S. Sinenko, M. Akbari, F. Asayesh, Determination of fundamental criteria in the selection of a construction system, In the collection: E3S Web of Conferences. Key Trends in Transportation Innovation, KTTI 2019.2020.S. 06025 https://doi.org/10.1051/e3sconf/202015706025

14. V. O. Chulkov, S. A. Sinenko, M. A. Fakhratov, M. Sh. Akbari, Classification of project cost overruns in the construction industry Bulletin of Eurasian Science, 5 (2019) Available at: https://esj.today/PDF/44SAVN519.pdf (Last accessed 2021/02/31) 